\title{
Labor market and crisis: an analysis of sectoral segmentation in Brazilian rural'
}

\author{
Mercado de trabalho e crise: uma análise da segmentação setorial no meio \\ rural brasileiro
}

Gabriela Gomes Mantovani ${ }^{1}$ (D), Jefferson Andronio Ramundo Staduto ${ }^{1}$ (D), Carlos Alves do Nascimento ${ }^{2}$ (1)

\begin{abstract}
'Programa de Pós-graduação em Desenvolvimento Regional e Agronegócio, Universidade Estadual do Oeste do Paraná (UNIOESTE), Toledo (PR), Brasil. E-mails: gmmantovani@gmail.com; jefferson.staduto@unioeste.br ${ }^{2}$ Instituto de Economia e Relações Internacionais, Programa de Pós-graduação em Economia, Universidade Federal de Uberlândia (UFU), Uberlândia (MG), Brasil. E-mail: carlos.nascimento@ufu.br
\end{abstract}

\begin{abstract}
How to cite: Mantovani, G. G., Staduto, J. A. R., \& Nascimento, C. A. (2022). Labor market and crisis: an analysis of sectoral segmentation in Brazilian rural. Revista de Economia e Sociologia Rural, 60(4), e249112. https://doi. org/10.1590/1806-9479.2021.249112
\end{abstract}

\begin{abstract}
The article aims to analyze which factors contributed to the inequality across income distribution of Brazilian workers in rural areas, occupied in agricultural and non-agricultural activities. Quantile regression with sample selection bias correction and counterfactual decomposition of income by quantiles were applied, using the microdata from the National Continuous Household Survey (PNAD-C) for the years 2012 and 2019. The results showed that there is income inequality favorable to workers occupied in non-agricultural activities concerning agricultural activities, which is intensive for those with lower incomes, as well as for those with high incomes. The presence of sectorial segmentation was also confirmed, of which the largest portion in 2012 corresponds to the labor market duality. However in 2019, in lower quantiles the segmentation obtained greater explanatory power for the difference in income between the groups, while in higher quantiles the theory of human capital prevailed.
\end{abstract}

Keywords: income differences, rural labor market, quantile regression, income decomposition.

Resumo: Este artigo visa investigar os fatores que contribuíram para a desigualdade de rendimentos e analisar os efeitos da segmentação ocupacional de trabalhadores brasileiros empregados em atividades agrícolas e não agrícolas, no meio rural. Foram aplicados os métodos de regressão quantílica com correção de viés de seleção amostral e a decomposição contrafactual de rendimentos por quantis, através dos microdados da Pesquisa Nacional por Amostra de Domicílios Contínua (PNAD-C) para os anos de 2012 e 2019. Os resultados mostraram que existe desigualdade de renda favorável aos trabalhadores empregados em atividades não agrícolas em relação aos designados em atividades agrícolas, sendo a diferença superior para aqueles trabalhadores com rendas mais baixas, assim como para aqueles com altos rendimentos. Confirmou-se ainda a presença da segmentação setorial, da qual a maior parcela em 2012 corresponde à dualidade do mercado de trabalho e em 2019, nos quantis inferiores, a segmentação obteve maior poder explicativo para a diferença de rendimentos entre os grupos, enquanto para os quantis superiores, a teoria do capital humano prevaleceu.

Palavras-chave: diferenças de renda, mercado de trabalho rural, regressão quantílica, decomposição de renda.

\section{INTRODUCTION}

The Brazilian rural areas in the last five decades have undergone intense social and economic transformations, led by the modernization process of the agricultural sector (Kageyama, 1990; Gasques \& Villa Verde, 1990). This worldwide phenomenon was known as the Green Revolution (Evenson \& Gollin, 2003; Pingali, 2012), which was implanted in several poor and developing countries from the decade of 1960 (Gasques et al., 2004; Resende, 2005; Freitas et al., 2007;

\footnotetext{
1 The present study was carried out with the support of the National Council for Scientific and Technological Development - Brazil (CNPq).
} 
Bortolotto et al., 2018). The sectoral policies of agriculture modernization were fundamental to the countless changes in the sector in Brazil and contributed to the country's economic development through the generation of surplus production for the domestic market and exports, as well as the national territory occupation by expanding agricultural borders and boosting inland cities far from large urban centers.

This agricultural modernization process has profoundly changed the technical basis of Brazilian production ${ }^{2}$, transforming the country at the beginning of this century into a major player in international trade as an exporter of agricultural and agro-industrial products, because the country has increased competitiveness in various production chains.

At the same time as the agricultural sector modernization process in Brazil and other countries, the families' income living diversification in rural areas become an important strategy to increase the quality of life and the level of livelihood. The average income from non-agricultural active contributes $40 \%$ of total rural income in Latin America; $42 \%$ in Africa and 32\% in Asia. These data demonstrate that non-agricultural income is a significant part of total income, being an important factor for the increase in purchasing power and food security (Reardon et al., 2007). In Brazil in $2019,50 \%$ of the rural income was made up of income from agricultural activities, and the other half came from non-agricultural activities (Instituto Brasileiro de Geografia e Estatística, 2019).

In rural areas of Brazil, diversification of both agricultural and non-agricultural activities increased intensely from the decade of 1990. However, the number of people occupied in agricultural activities decreases, simultaneously with an increase in the jobs supply from non-agricultural activities. The different activities diffusion in the rural area and improvement of the commuting process between rural areas and cities provided the greatest number of rural workers occupied in non-agricultural activities (Campanhola \& Silva, 2004; Mattei, 2015; Sakamoto et al., 2016; Aquino \& Nascimento, 2020).

The literature discusses the growing role of non-agricultural activities and the policymakers' interest to encourage non-agricultural activities in the rural area, to reduce rural poverty and increase local economic activity (Matshe \& Young, 2004; Pereira et al., 2017). However, few researchers have compared these two segments of workers - agricultural and non-agricultural -, and especially the difference in remuneration across the income distribution. The income gap can potentially be more social and economic deleterious if it is at the basis of income distribution compared to the top. The studies usually analyze the income average difference among segmented workers.

Given the above, the central objective of the article is to analyze which factors contributed to the inequality across income distribution between agricultural and non-agricultural workers residing in rural areas of Brazil, and how the evolution of sectorial segmentation in the Brazilian rural area occurred for these activities in the years 2012 and 2019. The two years in Brazil had different economic dynamics due to a deep economic and political crisis initiated in 2014, which has not been recovered yet. On the one hand, 2012 was a year of economic growth in all the economic sectors and low unemployment; on the other hand, 2019 had low growth and high unemployment, except for the agricultural sector that maintained reasonable dynamism in this time interval (Instituto de Pesquisa Econômica Aplicada, 2020; Instituto Brasileiro de Geografia e Estatística, 2020).

\section{INCOME DIFFERENCE: THEORETICAL AND EMPIRICAL APPROACH}

\subsection{Agricultural labor market: the Brazilian's background activities}

The modernization process of the Brazilian agricultural sector implanted in the '70s, contributed to the great rural exodus and reduced the small farmers' economic conditions, (Graziano da Silva,

2 In 2012, the agribusiness GDP corresponded to $R \$ 1,391.554$ million; and in 2018, this value increased to $\mathrm{R} \$ 1,436.372$ million, which represented 14\% of Brazil's total GDP (Centro de Estudos Avançados em Economia Aplicada, 2020). The monetary values corresponding to 2012 were corrected for 2019 on the basis of the National Consumer Prices Index (INPC). 
1999); it also had negatively impacted income levels and the degree of poverty in agriculture among the Brazilian regions (Hoffmann \& Kageyama, 1986). Also, it had a positive influence on Brazilian economic development and has contributed to the intensification of urbanization and industrialization processes, as well as helping the development of the metropolitan region and stimulated the migration process (Gasques et al., 2004; Resende, 2005; Freitas et al., 2007).

The agricultural labor market has had a major impact in the decade of 1970 with the reduction of the rural population. In this decade, the urban population in Brazil became larger than the rural population due to the intense rural-urban migration, in a short period altering the country's demographics, in a way that the rural population growth began to decrease about the urban population.

The labor market had an intense impact, mainly on the demand side due to the organization of production that concentrated the rural properties, and the establishment of the new law (workers' Statute and Land Law ${ }^{3}$ ) implemented in this decade that discouraged the traditional production arrangements (partnership, sharecropper and others). In addition, the technological advances that have hit the rural sector have increased demand for specialized labor and reduced the total number of jobs in the agricultural sector (Staduto et al., 2004), leading to a reduction in agricultural wages (Castro, 1971; Kageyama, 1990; Staduto et al., 2002; Staduto \& Kreter, 2014).

On the other hand, the readily available labor force saw their job opportunities increase in the rapidly expanding urban centers (Alves, 1995; Staduto et al., 2004; Cunha, 2009). In the early 1990s, the agricultural labor market again had a major impact on the technological innovation cycle. Such cycle advanced on the production of the tropical product, such as sugar cane, coffee, and orange, resulting in a further reduction in jobs in the agricultural production (Staduto et al., 2004; Alves \& Marra, 2009), which contributes to pressure the wages of these occupations down ${ }^{4}$ (Staduto et al., 2002).

\subsection{Agricultural and non-agricultural activities}

The workers increase in non-agricultural activities can be attributed to three factors: a) the idle time emergence in the field; b) to improve the income and consumption conditions (Kageyama, 2001); and c) to increase the jobs supply associated with non-agricultural occupations (tourism, leisure, housing, etc) for individuals living in rural areas, as well as higher wages (Laurenti \& Del Grossi, 2000; Graziano da Silva et al., 2002).

The non-agricultural activities expansion has the potential to finance agricultural activities (Reardon et al., 2007); non-agricultural activities generate agricultural productivity spillover (Liu, 2017) contributes to consumption and income by providing an increase in capital stock and by reducing underemployment (Lanjouw \& Lanjouw, 2001; Birthal et al., 2014; Anang \& Yeboah, 2019); generates spillover in local economic activity, assists in the knowledge and information propagation in the rural area (Davis et al., 2004; Nilsson, 2019); contributes to increasing women's empowerment, obtaining income outside the male productive sphere that is the agricultural production (Staduto et al., 2013). According to Matshe \& Young (2004), the interest of policymakers in public policies has been increasing to encourage non-agricultural activities in rural areas, through rural poverty reduction and increased local economic activity.

Sources of non-agricultural income are positively correlated with total income. The various sources of income and for various sizes of property suggest that the non-agricultural sector

\footnotetext{
3 Land law of 1850 prohibited free access to land, except through purchase. The Rural Worker's Statute approved in 1963, whose legal framework sought to regulate a number of aspects of rural work, both of paid employment and of relationships between farmers and owners, such as the agricultural partnership. However, this regulation represented more than thirty years of delay in relation to the urban worker in Brazil.

${ }^{4}$ Even characterized by the jobs reduction, the agricultural sector has made significant advances in the quality of jobs, including all categories of workers (Balsadi, 2007).
} 
can be a potential way for rural families with land restrictions to improve their income level (Birthal et al., 2014). In developing countries, non-agricultural activities play an important role in the sustainable development process and mainly to help reduce poverty in rural areas (Liu, 2017). Participation in these activities can also contribute to greater equality in income distribution (Janvry \& Sadoulet, 2001) and be part of a defensive survival strategy for rural area poor people (Davis \& Bezemer, 2003).

In the Northeastern region of Brazil, where there are large areas of extreme poverty, the average non-agricultural income is higher than the agricultural income, which shows that the income that comes from non-agricultural activities is an important family income component, mainly as a complementary household income element (Mariano \& Neder, 2006). In addition, workers with higher education have been the most beneficial ones (Pereira et al., 2017).

In a study for Mexico, Janvry \& Sadoulet (2001) found that incomes from non-agricultural activities of pluriactive families are more than half the income (55\%) of the total family income. They also found that education is a key factor in increasing workers' participation in non-agricultural activities. Another interesting fact is that indigenous adults suffer from educational lag, thus having less access to non-agricultural jobs than non-indigenous people with the same level of study.

Liu (2017) described that China has few arable lands, and the divergence between lack of land and excess labor is more critical in poor mountain areas, which generates low per capita income. Thus, non-agricultural activities are indispensable for the absorption of the surplus labor force, for the increase in income of those living in the field, as well as the rural poverty reduction. Chinese rural households obtain $67.0 \%$ of income from non-agricultural occupations, proving that their family income is higher than that of families participating only in agricultural activities. The difference of $65.8 \%$ in income between non-agricultural families and pure farmers derives from personal and productive characteristics. Non-agricultural participation is the most effective choice for increasing the Chinese rural families' income (Liu, 2017).

The increase in the rural and urban labor markets integration, the activities dynamics outside the agricultural economy influences the use of labor and the general sectoral composition of nonagricultural income (Reardon, 1999). The difference in income between rural workers - agricultural and non-agricultural - is due to the labor market segmentation. Thus, this study focuses on the sector of activity in which the rural worker is occupied in the Brazilian labor market, to verify the sources of income differences among individuals living in rural areas, which can be occupied into activities that involve this environment or not.

\subsection{Segmentation of the labor market}

Different theoretical currents explain the wage differences between the workers, considering the labor force heterogeneity. Among these, the theory of human capital can be cited, which aims to explain the wage gap according to the different amounts of worker's capital, through formal qualification or training (Mincer, 1958; Schultz, 1964; Becker \& Chiswick, 1966; Lima, 1980). The theory of discrimination explains that discrimination occurs when individuals with identical attributes are treated differently, based on irrelevant criteria (such as gender, skin color, etc.) for the activities they perform or on their productivity (Becker, 1957; Loureiro, 2003). The theory of segmentation (or dual market) shows the labor market duality, that is, the market is divided into two segments, these segments correspond to the primary and secondary markets 5 .

${ }_{5}^{5}$ The primary market is identified by jobs with stability, high incomes and productivity, greater possibilities for promotion within firms, etc. the secondary market is determined by high turnover of workers, low wages, poor working conditions, high unemployment rates, low qualification, instability, among other characteristics (Lima, 1980). 
The theory of labor market segmentation (LMS) comes from criticism of the neoclassical theory of wage dispersion that is based on human capital theory. Cain (1976) develops a deep analysis and reflection and concludes that LMS has its contribution to the neoclassical theory literature in two aspects: a) the idea of the variables endogenous determination that capture attitudes among workers; and b) considers the institutional and historical dimension of the internal labor market, which enriches the organizations economic understanding. In addition, LMS is a theory that provides a good description of the income distribution (Dickens \& Lang, 1993). The theories that adopt the segmented labor market approach, in general, differ from classical theory and some models of neoclassical labor market theory, fundamentally, because they assume such market, the institutionalization occurs (Carneiro, 1997). This is translated into a non-homogeneous labor market and the existence of non-competitive groups, when one presupposes the hypotheses relaxation of perfect mobility and labor force replacement.

The segmentation theoretical approach proposes a more comprehensive analysis of the labor market. The human capital theory is centered on the acquisition of education and other factors that increase the worker labor capacity, for example, the level of health and other unobserved skills, which reflect on labor productivity increasing. However, LMS also suggests that there is a strong workplace impact, the market structure, and the industry's technological level on the wage rate, and not exclusively the individual's level of education and experience. The workers are employed in several segments, and the dual form between the primary and secondary markets is the simplest way to segment the labor market (Lima, 1980; Taubman \& Wachter, 1986).

The differences in the point of view of labor market segmentation derive from the fact that researchers of this phenomenon point to different causes for its emergence, highlighting those that meet their ideological convictions and empirical observations. However, they consider that the main lines of dualistic thinking are complementary (Lima, 1980).

Cacciamali de Souza (1978) and Lima (1980) highlight three currents of thought that they consider as the main ones in terms of LMS theory. The first concerns the allocation adjustment, where the worker's attributes such as gender, skin color, schooling, experience, etc., will determine his or her job opportunities and in which market he or she will be designated (Doeringer \& Piore, 1970). The second focus highlights the defects in the labor market, of which the labor force characteristics are the motivators for the market discontinuity (Vietorisz \& Harrison, 1973). Finally, duality may occur due to the existence of social classes, and these are the segmentation process source (Reich et al., 1973). Agricultural workers are in the second segment in developing countries (Dickens \& Lang, 1993; Fields, 2009). In Brazil, agricultural production has a great technological gradient, but most of them have a low income. The present study was based on the segmentation theory to explain the differences in income among the Brazilian rural workers, who are occupied in agricultural or non-agricultural activities in rural areas.

\section{METHODOLOGY}

To perform this study, microdata of the National Continuous Household Survey (PNAD-C) were used for Brazil in the years 2012 and 2019, 2012 being the first research release and the year 2019, which covers the most recent data at the time of this study (Instituto Brasileiro de Geografia e Estatística, 2012, 2019). The 2012 year had low unemployment and economic growth, in contrast to the year 2019, with high unemployment rates and zero growth in the economy, so it is possible to analyze both periods with distinct dynamics (Instituto de Pesquisa Econômica Aplicada, 2020; Instituto Brasileiro de Geografia e Estatística, 2020). 
The sample analyzed is the occupied population aged $14^{6}$ years or over, who have positive incomes (employees with incomes, employers or self-employed persons) and domicile in the rural area, divided into two groups: the first is workers occupied in agricultural activities ${ }^{7}$, and the second group is workers occupied in non-agricultural activities. Thus, it is possible to analyze separately the residents of the rural area:

i) Agricultural activities: individuals who work in agricultural activities with incomes from this sector; ii) Non-agricultural activities: individuals who are occupied in another work that does not comprise the agricultural activities, although they have their domicile in the rural area.

The variables used to characterize the occupied workers, as well as the methods used in this study, are shown in Chart 1.

Chart 1. Variables description

\begin{tabular}{|c|c|}
\hline $\ln (\mathrm{W})^{8}$ & Natural logarithm of the usual income adjusted by working hours. \\
\hline \multicolumn{2}{|c|}{ Independent variables } \\
\hline $\mathrm{SCH}$ & Worker's qualification level. \\
\hline EXP & $\begin{array}{l}\text { Worker's years of experience (Age of the individual - } 5 \text { - age at which he or } \\
\text { she began working). }\end{array}$ \\
\hline EXP2 $^{2}$ & Variable experience squared. \\
\hline G & $=1$ if it is a woman, 0 otherwise. \\
\hline W & $=1$ if it is white, 0 otherwise. \\
\hline $\mathrm{F}$ & $=1$ if the individual works in the formal market, 0 otherwise. \\
\hline REGIO & $\begin{array}{l}\mathrm{N}:=1 \text { if it lives in the Northern region, } 0 \text { otherwise; } \\
\mathrm{NE}:=1 \text { if it lives in the Northeastern region, } 0 \text { otherwise; } \\
\mathrm{SE}:=1 \text { if it lives in the Southeastern region, } 0 \text { otherwise; } \\
\mathrm{S}:=1 \text { if it lives in the Southern region, } 0 \text { otherwise; } \\
\mathrm{MW}:=1 \text { if it lives in the Midwestern region, } 0 \text { otherwise; } \\
\text { DF: }=1 \text { if it lives in Distrito Federal, } 0 \text { otherwise; }\end{array}$ \\
\hline OCCUP & $\begin{array}{l}\text { MAN: }=1 \text { if it belongs to the occupation Manager, zero } 0 \text { otherwise; } \\
\text { SA: }=1 \text { if it belongs to the Professional occupation of Sciences and Arts, } 0 \\
\text { otherwise; } \\
\text { ML_TEC: }=1 \text { if it belongs to the occupation mid-level technician, } 0 \text { otherwise; } \\
\text { SERV: }=1 \text { if it belongs to the occupation Services, zero } 0 \text { otherwise; } \\
\text { AGR: }=1 \text { if it belongs to the occupation Agriculture, zero } 0 \text { otherwise; } \\
\text { PROD: If it belongs to the Production occupation (base occupation). }\end{array}$ \\
\hline OCCUP_POS & $\begin{array}{l}\text { EMP_E: if the individual is an employee, } 0 \text { otherwise; } \\
\text { EMP_ER: if the individual is an employer, } 0 \text { otherwise; } \\
\text { SF: if the individual is self-employed, } 0 \text { otherwise (base position); }\end{array}$ \\
\hline AGR_ACT & $=1$ if the individual is in agricultural activity, 0 otherwise. \\
\hline HI_PC* & Per capita household income. \\
\hline EAP* & $=1$ if the individual is an economically active person, 0 otherwise. \\
\hline URB* & $=1$ if the individual resides in the urban area, 0 otherwise. \\
\hline SPOUSE* & $=1$ if the individual is considered a spouse, 0 otherwise. \\
\hline HEAD_FAM* & $=1$ if the individual is considered a head of the family, 0 otherwise. \\
\hline CO_5* & Number of children the individual has from 0 to 5 years. \\
\hline C6_13* & Number of children the individual has from 6 to 13 years. \\
\hline
\end{tabular}
Source: Elaborated by the authors from the microdata of PNAD-C 2012 and 2019. Note: * only sampling bias correction procedure was used.

${ }^{6}$ In Brazil, the minimum age allowed for any work is 16 years of age, however, people aged 14 can work as a minor apprentice (Brasil, 2000).

7 The database used in this work (PNAD-C) defines agricultural activities, and those that involve the activities that involve agriculture and livestock.

8 The incomes of 2012 were inflated on the basis of the Broad National Consumer Prices Index (IPCA), with the objective of comparing the monetary terms of 2012 with those of 2019.

9 The variable 'experience' was obtained from the proxy defined by Mincer (1974), as shown in Chart 1. 
The sampling bias correction procedure proposed by Heckman (1979) was applied by the probit estimation model:

$P_{i}=\beta_{0}+\beta_{1} S C H_{i}+\beta_{2} E X P_{i}+\beta_{3} E X P_{i}^{2}+\beta_{4} W_{i}+\beta_{5} U R B_{i}+\beta_{6} S P O U S E_{i}+\beta_{7} H E A D_{-} F A M_{i}+\beta_{8} C 0_{-} 5_{i}+\beta_{9} C 6_{-} 13_{i}+\beta_{10} G_{i}+\beta_{11} H I_{-} P C_{i}+\mu_{i}$

Estimates were made of income equations by quantiles $\left(10^{\text {th }}, 30^{\text {th }}, 50^{\text {th }}, 70^{\text {th }}\right.$, and $\left.90^{\text {th }}\right)$ for Brazilian workers living in rural areas, occupied in agricultural and non-agricultural activities. The quantile equations allow more detailed analysis among the variables because they evaluate different distribution points of the dependent variable: workers with low, medium, and high incomes (Koenker \& Basset, 1978; Scicchitano, 2012). Quantile regression makes it possible to identify workers across the income distribution, on the other hand, non-quantile estimates produce results of the average behavior of the samples analyzed, thus reducing the analysis depth.

Quantile regression can be written as:

$Y_{i}=x_{i}^{\prime} \beta_{\theta}+\varepsilon_{\theta i}$

Quant $_{\theta}\left(Y_{i} / x_{i}^{\prime}\right)=x_{i}^{\prime} \beta_{\theta}$

The term Quant ${ }_{\theta}\left(Y_{i} / x_{i}^{\prime}\right)=x_{i}^{\prime} \beta_{\theta}$ corresponds to the conditional quantile of $Y_{i}$ real random variable $(i=1, \ldots, n)$ given $x_{i}^{\prime}$ (vector $K x 1$ of explanatory variables) and $\beta_{\theta}$ is a vector of parameters. Rewriting the equation and applying the dependent and independent variables (Chart 1) according to the sample used, after the correction proposed by Heckman (1979), we have:

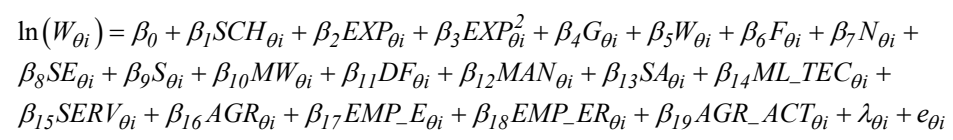

After the estimation of the quantile regressions, counterfactual wages decomposition of Oaxaca (1973) and Blinder (1973) was carried out across the income distribution, i.e., this method allows the breakdown of income differences by quantiles (Melly, 2005; Scicchitano, 2012). Based on estimates of quantile regressions, the conditional distribution $\ln (W)$ is integrated into the group of variables. Representing with $\hat{\beta}=\left(\hat{\beta}_{(\theta I)}, \ldots, \hat{\beta}_{(\theta j)}, \ldots, \hat{\beta}_{(\theta J)}\right)$ the vector of parameters estimated by the quantile regressions in the $j$ different quantiles $0<\theta_{j}<1$ with $j=1, \ldots, J$ and integrating into all quantiles and observations, an estimator of $\pi$-th unconditional quantile of the logarithm of the hourly income $[\ln (W)]$ is given by:

$q(\tau, x, \beta)=\inf \left(q: \frac{1}{N} \sum_{i=1}^{N} \sum_{j=1}^{J}\left(\theta_{j}-\theta_{j-1}\right) l\left(x_{i} \hat{\beta}\left(\theta_{j}\right) \leq q\right) \geq \tau\right)$

Where $1($.$) corresponds to an indicator function. Consequently, the income contrafactual$ distribution can be estimated by replacing the estimated parameters in the distribution of rural workers' attributes in agricultural or non-agricultural activities. The incomes decomposition for each quantile can be broken down into two components:

$$
q\left(\theta, x^{B}, \beta^{B}\right)-q\left(\theta, x^{A}, \beta^{A}\right)=\left[q\left(\theta, x^{B}, \beta^{B}\right)-q\left(\theta, x^{B}, \beta^{A}\right)\right]+\left[q\left(\theta, x^{B}, \beta^{A}\right)-q\left(\theta, x^{A}, \beta^{A}\right)\right]
$$

Where:

i) The superscript A represents the group in advantage (workers in non-agricultural activities), and the superscript $B$ is equivalent to the group in disadvantage (agricultural workers). 
ii) $\quad\left[q\left(\theta, x^{B}, \beta^{B}\right)-q\left(\theta, x^{B}, \beta^{A}\right)\right]$ constitutes the difference in the income returns those workers in different activities receive for their characteristics in the labor market, i.e. the contrafactual distribution (explained effect or composition effect);

iii) $\quad\left[q\left(\theta, x^{B}, \beta^{A}\right)-q\left(\theta, x^{A}, \beta^{A}\right)\right]$ corresponds to the inequalities effect in labor market characteristics between individuals involved in agricultural and non-agricultural activities. This is a proxy for the sectorial segmentation effect (returns effect, structure effect, or sectorial segmentation effect).

\section{RESULTS AND DISCUSSIONS}

\subsection{Descriptive Statistics}

The Brazilian population in 2012 was 197,721 thousand inhabitants, 15\% of whom lived in the countryside and $85 \%$ in cities. In 2019, the population was 209,496 thousand inhabitants, of which $86 \%$ lived in urban areas and $14 \%$ in rural areas (Instituto Brasileiro de Geografia e Estatística, 2012, 2020).

Workers occupied in agricultural activities had an average remuneration of $R \$ 1,103.58$ per month and $R \$ 6.33$ per hour in 2012; and $R \$ 1,108.38$ per month and $R \$ 6.72$ per hour in 2019 . Hourly income increased, but hours worked weekly on average reduced, resulting in a small increase in monthly income. The workers occupied in these activities have a low qualification profile, work about 38 hours a week, have 30 years of experience, the average age of 41 years old, most are men, non-white, head of the family, work in the informal labor market and reside in the Northeastern region (Table 1).

Workers occupied in non-agricultural activities had an average income of $R \$ 1,283.46$ and $\mathrm{R} \$ 8.35$ per month and hour, respectively, in 2012 , and $R \$ 1.260 .62$ per month and $R \$ 8.18$ per hour, in 2019, had higher income for the two years compared to workers in agricultural activities. However, income reduced from 2012 to 2019, reflecting the deep and severe performance of the Brazilian crises and affected more the non-agricultural activities.

Table 1. Characteristics of Brazilian rural workers occupied in agricultural and non-agricultural activities - 2012 and 2019

\begin{tabular}{lccccc} 
& \multicolumn{2}{c}{2012} & & 2019 \\
\cline { 2 - 3 } \cline { 5 - 6 } Variables & $\begin{array}{c}\text { Agricultural } \\
\text { activity }\end{array}$ & $\begin{array}{c}\text { Non- } \\
\text { agricultural } \\
\text { Activity }\end{array}$ & & $\begin{array}{c}\text { Agricultural } \\
\text { activity }\end{array}$ & $\begin{array}{c}\text { Non-agricultural } \\
\text { activity }\end{array}$ \\
Weekly worked hours & 38.74 & 38.32 & 37.56 & 36.60 \\
(average) & 30.12 & & & 30.65 & 23.82 \\
Experience (average) & 5.19 & 22.50 & & 6.28 & 9.10 \\
Years of study (average) & $1,103.58$ & $1,283.46$ & & $1,108.38$ & $1,260.62$ \\
Income month (average) & 6.33 & 8.35 & & 6.72 & 8.18 \\
Income hour (average) & 40.31 & 35.65 & & 41.93 & 37.91 \\
Age (average) & 23.62 & 44.61 & & 21.98 & 45.49 \\
Woman (\%) & 76.38 & 55.39 & & 78.02 & 54.51 \\
Man (\%) & 39.75 & 40.45 & & 36.46 & 36.92 \\
White (\%) & 60.25 & 59.55 & 63.54 & 63.08 \\
Nonwhite (\%) & 55.11 & 41.19 & 53.74 & 43.45 \\
Head of family (\%) & & & & \\
\hline
\end{tabular}

Source: Elaborated by the authors from the microdata of PNAD-C 2012 and 2019. 
Table 1. Continued,

\begin{tabular}{|c|c|c|c|c|}
\hline \multirow[b]{2}{*}{ Variables } & \multicolumn{2}{|c|}{2012} & \multicolumn{2}{|c|}{2019} \\
\hline & $\begin{array}{l}\text { Agricultural } \\
\text { activity }\end{array}$ & $\begin{array}{c}\text { Non- } \\
\text { agricultural } \\
\text { Activity }\end{array}$ & $\begin{array}{l}\text { Agricultural } \\
\text { activity }\end{array}$ & $\begin{array}{c}\text { Non-agricultural } \\
\text { activity }\end{array}$ \\
\hline Formal (\%) & 27.69 & 50.12 & 35.81 & 50.23 \\
\hline Informal (\%) & 72.31 & 49.88 & 64.19 & 49.77 \\
\hline Northern (\%) & 12.81 & 11.72 & 17.15 & 12.70 \\
\hline Northeastern (\%) & 41.65 & 43.41 & 34.73 & 41.75 \\
\hline Southern (\%) & 19.00 & 16.81 & 19.02 & 16.54 \\
\hline Southeastern & 21.22 & 23.27 & 21.69 & 24.00 \\
\hline Midwestern (\%) & 5.19 & 4.19 & 7.05 & 3.96 \\
\hline Distrito Federal (\%) & 0.13 & 0.60 & 0.36 & 1.05 \\
\hline $\begin{array}{l}\text { Number of sample } \\
\text { observations }\end{array}$ & $\begin{array}{c}29,067 \\
(60.27 \%)\end{array}$ & $\begin{array}{c}19,159 \\
(39.73 \%)\end{array}$ & $\begin{array}{c}25,069 \\
(56.15 \%)\end{array}$ & $\begin{array}{c}19,580 \\
(43.85 \%)\end{array}$ \\
\hline
\end{tabular}

Source: Elaborated by the authors from the microdata of PNAD-C 2012 and 2019.

Non-agricultural workers also experienced a reduction in the working day associated with a reduction in average remuneration per hour. In addition, they have 23 years of experience on average and low schooling, with about 8 years in 2012 and 9 years in 2019, although it is superior to workers in agricultural activities. The average age of these workers is 37 years, most of them are men, non-white, not the head of the family, working in the formal labor market, and live in the Northeastern region of the country (Table 1).

The women occupied in non-agricultural activities in rural areas accounted for $44.61 \%$ and $45.49 \%$ in 2012 and 2019, respectively. Such data highlight the importance of these workers for family income in the non-agricultural sector. They contribute to reducing the vulnerability of families living in rural areas, considering that more than $40 \%$ of them are occupied in nonagricultural activities (Table 1).

The majority of male and non-white workers in agricultural activities can be a sign of gender and skin color discrimination. The agricultural activities masculinization is observed when approximately $80 \%$ of workers occupied in agricultural activities are men. In addition, more than $60 \%$ of workers occupied in activities that involve rural areas are non-white (Table 1).

Another interesting point is the rural workers' informality. Although $50 \%$ of workers in non-agricultural activities have a "formal contract", that is, they are protected by Brazilian labor legislation, $72.31 \%$ in 2012 and $64.19 \%$ in 2019 of workers in agricultural activities do not have all the legal benefits (Table 1). These data represent the precariousness of the Brazilian rural labor market since the majority of workers occupied in agricultural activities do not have a formal contract or are unregistered entrepreneurs.

One factor that may be correlated to the worker's informal status in the labor market is the place of residence. For both years and activities, the largest percentage of workers reside in the Northeastern region of Brazil (Table 1). The Northeastern region is characterized as one of the most backward regions of the country and had the highest unemployment rate (14.5\%) in 2019 (Instituto de Pesquisa Econômica Aplicada, 2020). Therefore, workers employed in agricultural activities are less qualified professionals, with lower incomes and reside in one of the most problematic regions of the country, affected by unemployment and poverty (Soares et al., 2016). Besides, male and non-white superiority among rural workers has been proven. 
Similarly, to national and international studies (Mariano \& Neder, 2006; Janvry \& Sadoulet, 2001; Liu, 2017; Castro et al., 2020), it is verified that the income of non-agricultural activities is higher than the agricultural income. In addition, almost half of rural-based workers earn income from non-agricultural activities (39.73\% in 2012 and 43.85\% in 2019), suggesting a more stable alternative to increase the rural families' income (Liu, 2017).

The agricultural labor market has had a major impact with the reduction of the rural population due to technological advances (Staduto et al., 2004). The rural population adopted the activities strategy diversification (Ellis, 1998) seeking new jobs associated with non-agricultural occupations (Laurenti \& Del Grossi, 2000; Graziano da Silva et al., 2002). This fact can be observed in Table 1, using a decrease, albeit small, of workers occupied in agricultural activities from 2012 to 2019, concomitant with an increase in non-agricultural activities. This event is associated with the Brazilian economic dynamics in 2019, still not recovered from the crisis in previous years and characterized by high unemployment rates, 11.93\% (Instituto Brasileiro de Geografia e Estatística, 2020) and low economic growth with a $0.3 \%$ variation in national GDP, i.e. Brazilian GDP fell between 2012 and 2019, while the agricultural sector grew by 27.78\% (Instituto de Pesquisa Econômica Aplicada, 2020). In this case, the rural workers in non-agricultural activities are less vulnerable to economic shocks than those occupied in agricultural activities in rural areas.

According to the income quantiles, the first three quantiles $\left(10^{\text {th }}, 30^{\text {th }}\right.$, and $\left.50^{\text {th }}\right)$ of the rural workers distribution ${ }^{10}$ add more than $50 \%$ of the rural population for both activities (Table 2). Most of these workers are in the lowest income strata. Careful examination of these first quantiles contributes to analyzing the most vulnerable population mainly in rural populations. The impoverished population has less education, which reduces the chances of jobs that pay better. In the decade of 1990, the Brazilian Northeastern region concentrated the greatest rural poverty (Rocha, 1995, 2013) ${ }^{11}$.

In Brazil, the great regional socioeconomic disparity has not changed over the last decades. The Northern and Northeastern regions have the highest rates of poverty prevalence, especially the rural areas (Soares et al., 2016). For example, in the Northeastern region in 2001, the proportion of families below the poverty line was estimated at around $47 \%$ (Mariano \& Neder, 2004; De Melo Caldas \& Sampaio, 2015). This region presented one of the highest percentages of households without access to housing and consumption items, and in rural areas, it was a little more severe (De Melo Caldas \& Sampaio, 2015; Kreter et al., 2015). In this region, rural families have adopted non-agricultural activities as a strategy to skip to precarious social and economic status (Nascimento \& Cardozo, 2007) similar to other poor regions of the world (Janvry \& Sadoulet, 2001; Liu, 2017).

The regional disparity contributed to the great difference in the average income of rural workers in Brazil (Table 2). Despite the increase in hourly income in the period analyzed, the advantage of non-agricultural activities over agricultural activities was maintained. For example, the poorest workers in agricultural activities (quantiles $10^{\text {th }}, 30^{\text {th }}$, and $50^{\text {th }}$ ) earn an average of $\mathrm{R} \$ 3.16$ per hour in 2019 , while the richest (quantiles $70^{\text {th }}$ and $90^{\text {th }}$ ) receive an average of $\mathrm{R} \$$ 9.65 per hour in the same year. The non-agricultural activities follow the same behavior, with values of $R \$ 4.29$ and $R \$ 11.84$, respectively (Table 2 ). Most rural workers, that is, the poorest ones, are the most vulnerable and exposed due to their low pay.

\footnotetext{
${ }^{10}$ The rural workers are made up of employees, employers and self-employed persons residing in the rural area.

${ }^{11}$ Sen (1987) argues that poverty should not be attributed solely to income scarcity. The concept of poverty as capacity deprivation considers the notion of social justice - each person must have the freedom to make choices from his or her own framework, from what he or she values for himself or herself. According to Crespo \& Gurovitz (2002) relative deprivation incorporates the local and temporal variable, that is, deprivation can vary from one region to another, as well as over time in the same place.
} 
Table 2. Participation (\%) and average hourly income $(R \$)$ of Brazilian rural workers occupied in agricultural and non-agricultural activities by quantiles - 2012 and 2019

\begin{tabular}{|c|c|c|c|c|c|c|c|c|c|c|c|c|}
\hline \multirow{3}{*}{ Quantiles } & \multicolumn{6}{|c|}{ Agricultural activities } & \multicolumn{6}{|c|}{ Non-agricultural activities } \\
\hline & \multicolumn{3}{|c|}{2012} & \multicolumn{3}{|c|}{2019} & \multicolumn{3}{|c|}{2012} & \multicolumn{3}{|c|}{2019} \\
\hline & $\%$ & Cum & HI & $\%$ & Cum & HI & $\%$ & Cum & HI & $\%$ & Cum & HI \\
\hline $10^{\text {th }}$ & 11.15 & 11.15 & 1.32 & 11.13 & 11.13 & 1.37 & 10.65 & 10.65 & 2.23 & 11.11 & 11.11 & 2.26 \\
\hline $30^{\text {th }}$ & 22.20 & 33.35 & 2.95 & 22.44 & 33.57 & 3.15 & 22.68 & 33.33 & 4.64 & 22.25 & 33.36 & 4.80 \\
\hline $50^{\text {th }}$ & 23.26 & 56.61 & 4.46 & 21.76 & 55.33 & 4.95 & 22.23 & 55.56 & 6.05 & 22.17 & 55.53 & 5.79 \\
\hline $70^{\text {th }}$ & 21.20 & 77.81 & 6.17 & 23.77 & 79.10 & 6.93 & 22.21 & 77.77 & 8.52 & 21.94 & 77.47 & 8.66 \\
\hline $90^{\text {th }}$ & 22.19 & 100.00 & 11.64 & 20.90 & 100.00 & 12.37 & 22.23 & 100.00 & 14.75 & 22.53 & 100.00 & 15.01 \\
\hline
\end{tabular}

Source: Elaborated by the authors from the microdata of PNAD-C 2012 and 2019. Notes: (1) Cum - accumulated percentage; (2) HI - average hour income.

For both years ${ }^{12}$, agriculture occupies most of the workers engaged in agricultural activities (53\% in 2012 and 68\% in 2019), then the highest percentages correspond to the professions associated with services ${ }^{13}$ (43\% in 2012 and 28\% in 2019) (Figure 1). In rural areas agricultural occupations still prevail, in terms of proportion, there was a significant increase in 2019, when the non-agricultural sector had not recovered yet from the deep economic crisis in Brazil that started in 2014. Agricultural production had an important social and economic role in overcoming the crisis and reducing vulnerability, which was reflected in the increased participation of agricultural occupation in agricultural activities.

Most rural workers in non-agricultural activities have occupations of services and production ${ }^{14}$. For the two years, the occupations of services involved the majority of the workers in agricultural activities (54\% in 2012 and 55\% in 2019), followed by the jobs associated with production, 31\% and 30\% for 2012 and 2019, respectively (Figure 1).

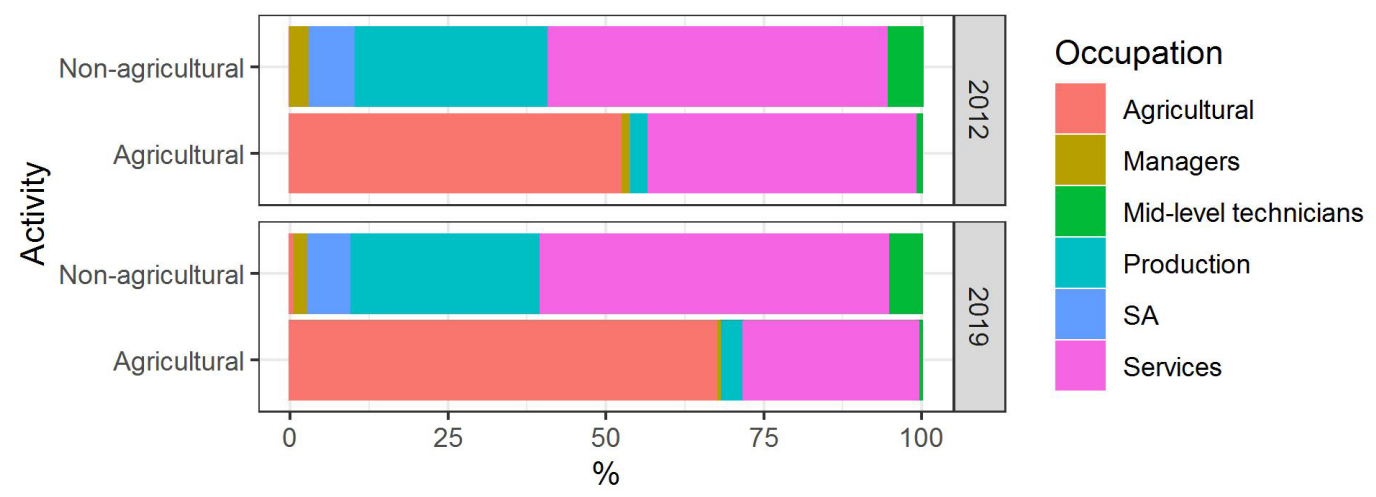

Figure 1. Participation (\%) of Brazilian rural workers occupied in agricultural activities and nonagricultural according to occupations - 2012 and 2019. Source: Elaborated by the authors from the microdata of PNAD-C 2012 and 2019. Note: SA - Professional occupation of Sciences and Arts.

\footnotetext{
${ }^{12}$ It is important to remind that occupations and activities are different concepts. Occupation is the function, position or job of the individual, while the activity concerns the economic activity sector. So, a worker may be occupied in the agricultural sector, but not necessarily engaged into an agricultural occupation.

${ }^{13}$ The enterprise activity sector may or may not have an association with the worker's job. For example, a driver may perform his or her occupation in the rural sector, driving agricultural machinery

${ }^{14}$ The occupations associated with production include skilled workers, workers and construction workers, mechanical arts and other equipment and machinery installations operators and assemblers.
} 


\subsection{Quantile regressions}

The quantile regressions for rural workers showed that the variables schooling and experience present positive returns corroborating the human capital theory (Mincer, 1958; Schultz, 1964; Becker \& Chiswick, 1966; Lima, 1980). Schooling had greater effects for extreme quantiles (quantiles $10^{\text {th }}$ and $90^{\text {th }}$ ), which contributes to increasing the distance of income between workers in agricultural and non-agricultural activities, while experience showed higher returns for those at the top of the distribution (quantiles $70^{\text {th }}$ and $90^{\text {th }}$ ), indicating that having more than one year of experience, the remuneration will be higher for workers with higher incomes than for the poorest ones.

Gender pointed to income losses for all quantiles and in both years. Women are paid less than men, and this difference is greater among those with low and medium incomes. In the behavior of the average income difference between rural population genders, no effect similar to the floor stick or ceiling glass was observed. The variable skin color showed gains, which highlights the remuneration inequality due to color. The returns to the white are higher for low-income workers, which indicates that color discrimination is higher for the poor when compared to those at the top of the distribution. These results evidenced discrimination by skin color (Becker,1957, 1971; Becker \& Chiswick, 1966; Castro et al., 2020) (Figure 2).

The variable of the formal labor market revealed gains in all quantiles compared to workers in the informal sector. The positive returns are higher for smaller quantiles $\left(10^{\text {th }}\right.$ and $\left.30^{\text {th }}\right)$. All the Brazilian regions presented gains when compared to the Northeastern region, highlighting that the returns are higher for the distribution base and in more developed and dynamic regions, contributing to income convergence among the regions. The occupations exhibited different performances concerning the production workers (base occupation) (Figure 2).

Employee or employer has revealed positive returns, which both receive higher incomes than the self-employed ones (base category), and the gains are higher for the employees allocated in the lower-income distribution layer (quantiles $10^{\text {th }}$ and $30^{\text {th }}$ ), and for the richest employers (quantiles $70^{\text {th }}$ and $90^{\text {th }}$ ).

Rural workers who are occupied in non-agricultural activities have had positive returns, and these are higher for those with lower incomes and those with high incomes (quantiles $10^{\text {th }}$ and $90^{\text {th }}$. This behavior reveals the rural labor market segmentation, and particularly the dual market approach (Doeringer \& Piore, 1970; Vietorisz \& Harrison, 1973; Reich et al., 1973; Lima, 1980; Carneiro, 1997; Castro et al., 2020). Workers in non-agricultural activities earn higher incomes than those occupied in agricultural activities due to the sector of activity in which they are occupied, whose earnings are higher when workers have lower or very high incomes. Moreover, this income gain (when compared to agricultural workers) contributes to an increase in the total income of households in the lower-income strata, that has lower schooling and less qualified professions, that is, the vulnerable population group (Figure 2).

The coefficients estimated for non-agricultural activities for 2019 are lower than those for 2012. In 2012, workers occupied in non-agricultural activities received $18 \%$ and $28 \%$ more than those occupied in agricultural activities in the quantiles of $10^{\text {th }}$ and $90^{\text {th }}$, respectively. For the year 2019, the percentages correspond to $16 \%$ and $14 \%$, in this order. This reduction in the difference between the two groups of activities was still a reflection of the deep crisis that began in 2014, which affected the urban and industrial activities more intensely, even so, there was an important disparity between the agricultural and non-agricultural rural workers (Figure 2). 

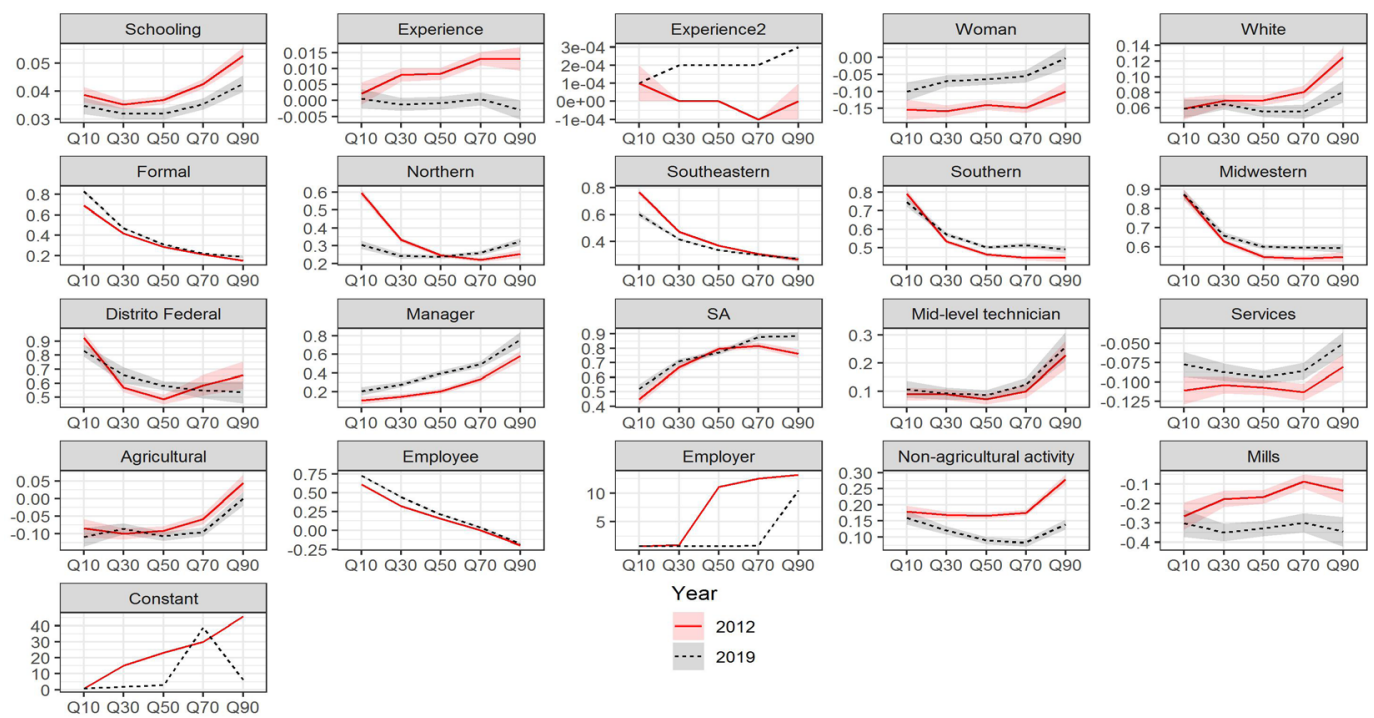

Q10 Q30 Q50 Q70 Q9
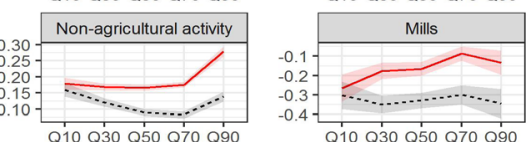

Figure 2. Results of quantile regressions for Brazilian rural workers - 2012 and 2019. Source: Elaborated by the authors based on the results of the quantile regressions. Notes: (1) Standard deviation was calculated by 100 bootstrap replications; (2) SA - Professional occupation of Sciences and Arts.

\subsection{Incomes Decompositions}

Brazilian rural workers occupied in agricultural and non-agricultural activities have differences in incomes (Figure 2). This disparity results from two dimensions: the workers' characteristics or sectorial segmentation. The decomposition method of Oaxaca (1973) and Blinder (1973) income was applied to the quantiles (Table 3 ) to measure the contributions of these two dimensions.

For 2012, the duality effect on the labor market is too high, mainly for the quantiles $10^{\text {th }}$ and $70^{\text {th }}$. The effect explained by the worker's personal and productive characteristics was not significant in all the quantiles. This demonstrates that the activity that the individual exercises has a greater ability to explain the difference in incomes than its attributes (Table 3 ).

In 2019 there was a different behavior compared to 2012. In the quantiles $10^{\text {th }}, 30^{\text {th }}, 50^{\text {th }}$, and 70 th, the segmentation effect was greater than 50\%, which indicates that the labor market duality was the main responsible for income inequality among these workers (Table 3). In 2019, the labor market segmentation is the main source of income difference for those who earn medium and low incomes.

Table 3. Decomposition of Oaxaca-Blinder income by quantiles for Brazilian rural workers occupied in agricultural and non-agricultural activities - 2012 and 2019

\begin{tabular}{|c|c|c|c|c|c|}
\hline \multirow{2}{*}{ Quantile } & \multicolumn{5}{|c|}{2012} \\
\hline & $10^{\text {th }}$ & $30^{\text {th }}$ & $50^{\text {th }}$ & $70^{\text {th }}$ & $90^{\text {th }}$ \\
\hline \multicolumn{6}{|l|}{ Effect explained } \\
\hline \multirow[t]{2}{*}{ Coefficients } & -0.0318 & 0.0492 & 0.0310 & -0.0545 & -0.0032 \\
\hline & $-6.56 \%$ & $9.87 \%$ & $11.66 \%$ & $-18.14 \%$ & $-1.27 \%$ \\
\hline
\end{tabular}

Source Elaborated by the authors from the microdata of PNAD-C 2012 and 2019. Notes: (1) Significant $(*) p<0.01,\left({ }^{* *}\right)$ $p<0.05$, $(* * \star) p<0.10$, with no asterisk, were not statistically significant. (2) Advantage group: Rural workers occupied in non-agricultural activities. 
Table 3. Continued...

\begin{tabular}{|c|c|c|c|c|c|}
\hline \multirow{2}{*}{ Quantile } & \multicolumn{5}{|c|}{2012} \\
\hline & $10^{\text {th }}$ & $30^{\text {th }}$ & $50^{\text {th }}$ & $70^{\text {th }}$ & $90^{\text {th }}$ \\
\hline \multicolumn{6}{|c|}{ Sectorial segmentation effect } \\
\hline \multirow[t]{2}{*}{ Coefficients } & $0.5170^{*}$ & $0.4495^{*}$ & $0.2348 *$ & $0.3550 *$ & 0.2597 \\
\hline & $106.56 \% *$ & $90.13 \% *$ & $88.34 \% *$ & $118.14 \% *$ & $101.27 \%$ \\
\hline \multicolumn{6}{|l|}{ Total difference } \\
\hline \multirow[t]{2}{*}{ Coefficients } & $0.4852 *$ & $0.4987 *$ & $0.2658 *$ & $0.3005^{*}$ & $0.2564 *$ \\
\hline & $100.00 \% *$ & $100.00 \% *$ & $100.00 \% *$ & $100.00 \% *$ & $100.00 \% *$ \\
\hline \multirow{2}{*}{ Quantile } & \multicolumn{5}{|c|}{2019} \\
\hline & $10^{\text {th }}$ & $30^{\text {th }}$ & $50^{\text {th }}$ & $70^{\text {th }}$ & $90^{\text {th }}$ \\
\hline \multicolumn{6}{|l|}{ Effect explained } \\
\hline \multirow[t]{2}{*}{ Coefficients } & 0.0273 & $0.1908^{*}$ & $0.0921 * *$ & $0.1209^{* *}$ & 0.1145 \\
\hline & $5.63 \%$ & $39.52 \%$ * & $40.89 \% * *$ & $49.42 \% * *$ & $65.21 \%$ \\
\hline \multicolumn{6}{|c|}{ Sectorial segmentation effect } \\
\hline \multirow[t]{2}{*}{ Coefficients } & $0.4571^{*}$ & $0.2920 *$ & $0.1332 *$ & $0.1238 * *$ & 0.0611 \\
\hline & $94.37 \% *$ & $60.48 \% *$ & $59.58 \% *$ & $50.58 \% * *$ & $34.79 \%$ \\
\hline \multicolumn{6}{|l|}{ Total difference } \\
\hline \multirow[t]{2}{*}{ Coefficients } & $0.4844 *$ & $0.4828 *$ & $0.2253^{*}$ & $0.2447 *$ & $0.1756^{*}$ \\
\hline & $100.00 \% *$ & $100.00 \% *$ & $100.00 \% *$ & $100.00 \% *$ & $100.00 \%$ * \\
\hline
\end{tabular}

Source Elaborated by the authors from the microdata of PNAD-C 2012 and 2019. Notes: (1) Significant $(*) p<0.01,(* *)$ $p<0.05$, (***) $p<0.10$, with no asterisk, were not statistically significant. (2) Advantage group: Rural workers occupied in non-agricultural activities.

The results for both years demonstrate that there is a difference in income among the Brazilian rural workers, being that individuals occupied in non-agricultural activities have higher incomes when compared to those in agricultural activities (Figure 2). In addition, the segmentation effect was higher than the effect explained by the workers' characteristics and attributes for all the quantiles in 2012, except for the last quantile that was not significant. On the other hand, for 2019, the segmentation explained most of the income differences for the quantiles $10^{\text {th }}, 30^{\text {th }}$, $50^{\text {th }}$, and $70^{\text {th }}$, which represent those with low and medium incomes (Table 3).

Different realities are observed in the Brazilian economy in 2012 and 2019. In 2012, the Brazilian economy was in a dynamic cycle, with a low unemployment rate of $7.4 \%$ (Instituto Brasileiro de Geografia e Estatística, 2020) and a high growth rate of economic activity, mainly in the agricultural sector. However, in 2019, with no total recovery from the recession of previous years, Brazil had a high unemployment rate (11.9\%) (Instituto Brasileiro de Geografia e Estatística, 2020) and low economic growth. In the period from 2012 to 2019, the national GDP variation was almost zero (0.27\%) and, on the other hand, GDP in the agricultural sector grew by $27.78 \%$. For example, growth in 2019 was only $1.1 \%$ concerning the previous year, the Brazilian economy was still in a slow process of economic growth, again in 2020 it will have an abrupt fall due to the COVID-19 pandemic (Instituto de Pesquisa Econômica Aplicada, 2020).

In the period studied, there were no major motivations of the agricultural sector for the original displacement of the income disparity among the activities, however, the economy had a very poor performance. In the dynamic periods - for example, 2012 -, the segmentation theory approach prevails to explain the difference among the incomes of individuals working 
in rural areas. In the year 2019, marked by a period of crisis, the dual market theory shows greater power of explanation for the differences in incomes among the workers with low and middle incomes; on the other hand, for workers with higher incomes, the human capital theory prevails to explain the differences in the incomes (Table 3).

\section{FINAL CONSIDERATIONS}

This research aimed to analyze what factors contributed to the inequality across income distribution between agricultural and non-agricultural workers residing in rural area. The income distribution was stratified in quantiles $\left(10^{\text {th }}, 30^{\text {th }}, 50^{\text {th }}, 70^{\text {th }}\right.$, and $\left.90^{\text {th }}\right)$, using the microdata from PNAD-C for the years 2012 and 2019, to obtain the effects of the explanatory variables in different points of the variable "logarithm of hourly income".

The results confirm the difference in incomes among the rural workers, and the dispersion is greater for the distribution base, that is, the poorest ones. In 2012, the effect of sectorial segmentation contributed mostly to the income difference in all the quantiles, while in 2019, the sectorial segmentation had greater power of influence on income inequality in four quantiles $\left(10^{\text {th }}, 30^{\text {th }}, 50^{\text {th }}\right.$, and $\left.70^{\text {th }}\right)$, representing those with low and medium incomes.

The results also highlight the women's importance for the family income in non-agricultural activities, $40 \%$ of them work in activities not related to non-agricultural activities. The women's income contributes to reducing the families living in rural areas because they mostly spend on the most vulnerable family members - children and the elderly.

The Brazilian economic dynamics influences the income disparity, so that in periods with high GDP growth and low unemployment, the difference in income is the labor market segmentation, that is, it depends mainly on the sector of activity that the worker is employed. In a low growth period, the segmentation theory is also expressed as a source of income differences between workers on the basis and in the middle of the income distribution, while the human capital theory is the source of income inequalities in the superior distribution strata.

The results contribute to supporting the public policies formulation directed toward rural area that aims to encourage non-agricultural activities in the field. These policies can promote poverty reduction and increased economic activity at the local, as well as the income inequality reduction and sectorial segmentation generated by the labor market. It is not possible anymore to talk about the separation of rural and urban societies, given their greater interdependence motivated by the growing commuting process. There is still an important gap between the traditional instruments used by public policies to regulate and develop agricultural activities and the new problems (in addition to agriculture) that arise in the rural area.

Therefore, rural development policies can no longer be targeted only at modern and viable producers, because agriculture plays not only a productive role but also the maintenance of an articulated social fabric in an increasingly wider rural area than the agricultural sphere. Consequently, it is necessary to emphasize the importance of pluriactivity and occupations in non-agricultural activities among the rural residents in the formulation of rural development programs.

\section{AGRADECIMENTOS}

Jefferson Andronio Ramundo Staduto: Bolsista produtividade CNPq. 


\section{REFERENCES}

Alves, E. (1995). Migração rural-urbana. Revista de Política Agrícola, 4(4), 15-29.

Alves, E., \& Marra, R. (2009). A persistente migração rural-urbano. Revista de Política Agrícola, $18(4), 5-17$

Anang, B. T., \& Yeboah, R. W. N. (2019). Determinants of off-farm income among smallholder rice farmers in northern Ghana: application of a Double-Hurdle model. Advances in Agriculture, 2019(7).

Aquino, J. R., \& Nascimento, C. A. (2020). Heterogeneidade e dinâmicas das fontes de ocupação e renda das famílias rurais nos estados do Nordeste brasileiro. Revista Grifos, 29(50), 126-148.

Balsadi, O. V. (2007). O mercado de trabalho assalariado na cultura da cana-de-açúcar, noBrasil, no período 1992-2005. Revista de Política Agrícola, 16(2), 34-43.

Becker, G. S. (1957). The economics of discrimination. Chicago: The University of Chicago Press.

Becker, G. S. (1971). The economics of discrimination (2nd ed.). Chicago: The University of Chicago Press.

Becker, G. S., \& Chiswick, B. R. (1966). Education and the distribution of earnings. The American Economic Review, 56(2), 358-369.

Birthal, P. S., Negi, D. S., Jha, A. K., \& Singh, D. (2014). Income sources of farm households in India: Determinants, distributional consequences and policy implications. Agricultural Economics Research Review, 27(1), 37-48.

Blinder, A. S. (1973). Wage discrimination: reduced form and structural estimates. The Journal of Human Resources, 8(4), 436-455.

Bortolotto, C. C., Mola, C. L., \& Tovo-Rodrigues, L. (2018). Qualidade de vida em adultos de zona rural no Sul do Brasil: estudo de base populacional. Revista de Saúde Pública, 52(Supl. 1), 1-11.

Brasil. (2000). Lei no 10.097 de 19 de dezembro de 2000. Lei ordinária: artigos 402 e 403. Diário Oficial [da] República Federativa do Brasil, Brasília. Recuperado em setembro de 2019, de http://www.planalto.gov.br/ccivil_03/leis/L10097.htm

Cacciamali de Souza, M. C. (1978). Mercado de trabalho: abordagens duais. Revista de Administração de Empresas, 18(1), 59-69.

Cain, G. I. (1976). The challenge of segmented labor Market theories to orthodox theory: a survey. Journal of Economic Literature, 14(4), 1215-1257.

Campanhola, C., \& Silva, J. G. (2004). O novo rural brasileiro: rendas das famílias rurais. Embrapa Informação Tecnológica.

Carneiro, F. G. (1997). Efficiency wages, insiders-outsiders e determinação de salários: teorias e evidência. Revista de Economia Política, 17(2), 110-129.

Castro, A. B. (1971). A industrialização descentralizada no Brasil. In Sete ensaios de economia brasileira. Rio de Janeiro: Forense.

Castro, N. R., Barros, G. S. C., Almeida, A. N., Gilio, L., \& Morais, A. C. P. (2020). The Brazilian agribusiness labor market: measurement, characterization and analysis of income differentials. Revista de Economia e Sociologia Rural, 58(1), 1-20.

Centro de Estudos Avançados em Economia Aplicada - CEPEA. 2020. PIB do agronegócio brasileiro. Recuperado em fevereiro de 2020, de https://www.cepea.esalq.usp.br/br/pibdo-agronegocio-brasileiro.aspx 
Crespo, A. P. O., \& Gurovitz, E. (2002). A pobreza como um fenômeno multidimensional. RAE Eletrônica, 1(2), 1-11.

Cunha, M. S. (2009). Evolução do emprego e dos salários no setor agropecuário brasileiro: trabalho temporário e permanente. Revista de Economia Agrícola, 56(1), 89-101.

Davis, J. R., \& Bezemer, D. (2003). Key emerging and conceptual issues in the developmen of the RNFE in developing countries and transition economies. SSRN, 693061.

Davis, J. R., Bezemer, D. J., Janowski, M., \& Wandschneider, T. (2004). The rural non farm economy and poverty alleviation in Armenia, Georgia and Romania: a synthesis of findings. SSRN. http://dx.doi.org/10.2139/ssrn.695183

De Melo Caldas, R., \& Sampaio, Y. S. B. (2015). Poverty in Brazilian northeast: a multidimensional analysis. Revista de Economia Contemporânea, 19(1), 74-96.

Dickens, W. T., \& Lang, K. (1993). Labor market segmentation theory: reconsidering the evidence. In W. Darity (Ed.), Labor economics: problems in analyzing labor markets (Recent Economic Thought Series, No. 29, pp. 141-180). https://doi.org/10.1007/978-94-011-2938-16

Doeringer, P. B., \& Piore, M. J. (1970). Internal labor markets and manpower analysis. Cambridge: Harvard University, MIT.

Ellis, F. (1998). Household strategies and rural livelihood diversification. The Journal of Development Studies, 35(1), 1-38.

Evenson, R. E., \& Gollin, D. (2003). Assessing the impact of the Green Revolution. Science, 300(5620), 758-762.

Fields, G. S. (2009). Segmented labor market models in developing countries. In H. Kincaid \& D. Ross (Eds.), The Oxford handbook of philosophy of economics (pp. 476-510). Oxford: Oxford University Press

Freitas, C. A., Bacha, C. J. C., \& Fossatti, D. M. (2007). Avaliação do desenvolvimento do setor agropecuário no Brasil: período de 1970 a 2000. Economia e Sociedade, 16(1), 111-124.

Gasques, J. G., \& Villa Verde, C. M. (1990). Crescimento da agricultura brasileira e política agrícola nos anos oitenta (Texto para Discussão, No. 204, 22 p.). Brasília: IPEA.

Gasques, J. G., Rezende, G. C., Villa Verde, C. M., Salerno, M. S., Conceição, J. C. P. R., \& Carvalho, J. C. S. (2004). Desempenho e crescimento do agronegócio no Brasil(Texto para Discussão, No. 1009, 22 p.). Brasília: IPEA.

Graziano da Silva, J. (1999). O novo rural brasileiro. Campinas: Unicamp.

Graziano da Silva, J., Del Grossi, M., \& Campanhola, C. (2002). O que há de realmente novo no rural brasileiro. Cadernos de Ciência \& Tecnologia, 19(1), 37-67.

Heckman, J.J. (1979). Sample selections bias as a specification error. Econometrica, 47(1), 153-161.

Hoffmann, R., \& Kageyama, A. (1986). Distribuição da renda no Brasil entre famílias e entre pessoas, 70 e 80. Estudos Econômicos. Instituto de Pesquisas Econômicas, 16(1), 25-51.

Instituto Brasileiro de Geografia e Estatística - IBGE. (2012). Pesquisa Nacional por Amostra de Domicílio - Contínua (PNAD-C). Rio de Janeiro: IBGE. Recuperado em dezembro de 2019, de http://www.ibge.gov.br

Instituto Brasileiro de Geografia e Estatística - IBGE. (2019). Pesquisa Nacional por Amostra de Domicílio - Contínua (PNAD-C). Rio de Janeiro: IBGE. Recuperado em abril de 2019, de http://www.ibge.gov.br 
Instituto Brasileiro de Geografia e Estatística - IBGE. (2020). Pesquisa Nacional por Amostra de Domicílio - Contínua (PNAD-C)(Séries Históricas). Rio de Janeiro: IBGE. Recuperado em abril de 2020, de https://www.ibge.gov.br/estatisticas/sociais/trabalho/17270-pnad continua. html?edicao $=26413 \& \mathrm{t}=$ series-historicas

Instituto de Pesquisa Econômica Aplicada - Ipea. (2020). Base de dados do Instituto de Pesquisa Econômica Aplicada: Ipea data. Recuperado em abril de 2020, de http://www.ipeadata.gov.br

Janvry, A., \& Sadoulet, E. (2001). Income strategies among rural households in Mexico: the role of off-farm activities. World Development, 29(3), 467-480.

Kageyama, A. (1990). O novo padrão agrícola brasileiro: do complexo rural aos complexos agroindustriais. In G. C. Delgado, J. G. Gasques \& C. V. M. Verde (Eds.), Agricultura e políticas públicas (Vol. 1, pp. 113-223). Rio de Janeiro: IPEA.

Kageyama, A. (2001). As múltiplas fontes de renda das famílias agrícolas brasileiras. Agricultura em São Paulo, 48(2), 57-69.

Koenker, R., \& Basset, G. (1978). Regression quantiles. Econometrica, 46(1), 33-50.

Kreter, A. C., Del-Vecchio, R., \& Staduto, J. A. R. (2015). Condições habitacionais como um indicador de pobreza nas áreas rurais do Nordeste brasileiro. Revista Economica do Nordeste, 46(1), 77-96.

Lanjouw, J. O., \& Lanjouw, P. (2001). The rural non-farm sector: issues and evidence from developing countries. Agricultural Economics, 26(1), 1-23.

Laurenti, A. C., \& Del Grossi, M. E. (2000). A evolução das pessoas ocupadas nas atividades agrícolas e não-agrícolas nas áreas rurais do Brasil. In C. Campanhola \& J. Graziano da Silva (Eds.), O novo rural brasileiro: uma análise nacional e regional. Jaguariúna: EMBRAPA.

Lima, R. (1980). Mercado de trabalho: o Capital Humano e a teoria da segmentação. Pesquisa e Planejamento Economico, 10(1), 217-272.

Liu, Y. (2017). Pushed out or pulled in? Participation in non-farm activities in rural China. China Agricultural Economic Review, 9(1), 111-129.

Loureiro, P. R. A. (2003). Uma resenha teórica e empírica sobre economia da discriminação. Revista Brasileira de Economia, 57(1), 125-157.

Mariano, J. L., \& Neder, H. D. (2004). Renda e pobreza entre famílias no meio rural do Nordeste. In Anais do Encontro Nacional de Economia Política. Uberlândia.

Mariano, J. L., \& Neder, H. D. (2006). Desigualdade de renda e pobreza entre famílias no meio rural do Nordeste. Revista de Economia \& Desenvolvimento, 5(2), 221-242.

Matshe, I., \& Young, T. (2004). Off-farm labour allocation decisions in small-scale rural households in Zimbabwe. Agricultural Economics, 30(3), 175-186.

Mattei, L. (2015). Emprego agrícola: cenários e tendências. Estudos Avançados, 29(85), 35-52.

Melly, B. (2005). Decomposition of differences in distribution using quantile regression. Labour Economics, 12(4), 577-590.

Mincer, J. (1958). Investment in human capital and personal income distribution. Journal of Political Economy, 66(4), 281-302.

Mincer, J. (1974). Schooling, experience and earnings. New York: National Bureau of Economic Research. 
Nascimento, C. A., \& Cardozo, S. A. (2007). Redes urbanas regionais e a pluriatividade das famílias rurais no Nordeste e no Sul do Brasil, 1992-1999 e 2001-2005. Revista Economica do Nordeste, 38(4), 637-658.

Nilsson, P. (2019). Spatial spillovers and households' involvement in the non-farm sector: evidence from rural Rwanda. Regional Studies, 53(5), 731-740.

Oaxaca, R. (1973). Male-female wage differentials in urban labor market. International Economic Review, 14(23), 693-709.

Pereira, A. F. C., Justo, W. R., \& Lima, J. R. F. (2017). Impactos das rendas não agrícolas sobre os indicadores de pobreza FGT para as famílias rurais pernambucanas. Revista de Ciências Agrárias, 40(1), 290-302.

Pingali, P. L. (2012). Green revolution: impacts, limits, and the path ahead. Proceedings of the National Academy of Sciences of the United States of America, 109(3), 112302-112308.

Reardon, T. (1999). Rural non-farm income in developing countries. Rome: FAO.

Reardon, T., Berdegué, J., Barrett, C. B., \& Stamoulis, K. (2007). Household income diversification into rural nonfarm activities. In S. Haggblade, P. B. R. Hazell, T. Reardon \& T. A. Reardon (Eds.). Transforming the rural nonfarm economy: opportunities and threats in the developing world (pp. 115-140). Baltimore: Johns Hopkins University Press.

Reich, M., Gordon, D. M., \& Edwards, R. C. (1973). Dual labor markets: a theory of labor market segmentation. The American Economic Review, 63(2), 359-365.

Resende, G. C. (2005). Políticas trabalhista e fundiária e seus efeitos adversos sobre o emprego agrícola, a estrutura agrária e o desenvolvimento territorial rural no Brasil (Texto para Discussão, No. 1108, 31 p.). Rio de Janeiro: IPEA.

Rocha, S. (1995). Governabilidade e pobreza: o desafio dos números (Texto para Discussão, No. 368). Rio de Janeiro: IPEA. Recuperado em junho de 2020, de http://repositorio.ipea. gov.br/bitstream/11058/1730/1/td_0368.pdf

Rocha, S. (2013). Pobreza no Brasil: a evolução de longo prazo (1970-2011)(Estudos e Pesquisas, No. 492). Rio de Janeiro: Instituto Nacional de Altos Estudos (INAE).

Sakamoto, C. S., Nascimento, C. A., \& Maia, A. G. (2016). As famílias pluriativas e não agrícolas no Rural Brasileiro: condicionantes e diferenciais de renda. Economia e Sociologia Rural, 54(3), 561-582.

Schultz, T. W. (1964). O valor econômico da educação. Rio de Janeiro: Zahar Editores.

Scicchitano, S. (2012). The male-female pay gap across the managerial workforce in the United Kingdom: a semi-parametric decomposition approach. Applied Economics Letters, 19(13), 1293-1297.

Sen, A. (1987). Hunger and entitlements. Helsinki: Wider.

Soares, S., Souza, L., Silva, W. J., \& Silveira, F. G. (2016). Perfil da pobreza: Norte e Nordeste rurais (IPC-IG Working Paper, No. 138). Brasília: International Polict Centre for Inclusive Growth.

Staduto, J. A. R., \& Kreter, A. C. (2014). A questão agrária e o mercado de trabalho rural no Brasil. Informe Gepec, 18(1), 177-192.

Staduto, J. A. R., Bacha, C. J. C., \& Bacchi, M. R. P. (2002). Determinação dos salários na agropecuária brasileira. Pesquisa e Planejamento Economico, 32(2), 285-321.

Staduto, J. A. R., Nascimento, C. A., \& Souza, M. (2013). Ocupações e renda das mulheres e homens no rural do estado do Paraná, Brasil: uma perspectiva de gênero. Cuadernos de Desarrollo Rural, 10(72), 91-115. 
Staduto, J. A. R., Shikida, P. F. A., \& Bacha, C. J. C. (2004). Alteração na composição da mão de obra assalariada na agropecuária brasileira. Agricultura em São Paulo, 51(2), 57-70.

Taubman, P., \& Wachter, M. (1986). Segmented labor markets. In O. Ashenfelter \& R. Layard (Eds.), Handbook of labor economics (Vol. 2, pp. 1183-1217). Amsterdam.

Vietorisz, T., \& Harrison, B. (1973). Labor market segmentation: positive feedback and divergent development. The American Economic Review, 63(2), 366-376. 